\title{
A Decade Later: The Impact of Empowerment on Women in Sitio Alitaptap, Province of Nueva Ecija, Philippines and Its Effect on Peace and Social Order
}

\author{
Jacinto Y. Bustamante \\ Correspondence: Jacinto Y. Bustamante, Nueva Ecija University of Science and Technology,Philippines.
}

Received: September 15, 2020 Accepted: October 9, 2020 Online Published: October 15, 2020

doi:10.11114/ijlpa.v3i2.5015

URL:https://doi.org/10.11114/ijlpa.v3i2.5015

\begin{abstract}
This study examined the impact of empowerment on women after a decade of its rigid campaign in the province of Nueva Ecija, Philippines and its effect on peace and social order as perceived by the residents of sitio Alitaptap, Nueva Ecija. The researcher utilized a descriptive research design using a self-devised questionnaire to gather information. The findings revealed that the respondents have a high level of conformity to the actions of local government unit to empower women. As to the impact of empowerment on women, the respondents agreed to the positive result of the action taken by the local government unit. The study showed that empowering women brought peace and social order and the quality of program implementation in the place caused high degree of effectiveness in the performance of duty of local officials. However, there are some things that are not clear to the respondents as there are some questions where respondents stand neutral. The study revealed that not only will women gain knowledge of their rights on the action of the local government but will also teach men how to respect women. The only negative result of the study is the threat that women may use their rights to prejudice men that may result in social disorder.
\end{abstract}

Keywords: empowerment on women, local government unit, social peace, social order

\section{Introduction}

Women have been suffering from discrimination, injustice and inequality all over the world. They are always dominated by men and became the most oppressed people. This may be the result of biological differences between women and men. In the Philippines, the respect for women is almost forgotten by the Filipinos of new generation and their value is almost no longer recognized.

Men and women were born with characteristic differences, ability, knowledge, and scope of power. They were created having duties and responsibilities according to their ability. From the time they were born they have assigned role to play in the society. Men have natural strengths and abilities than women and women have abilities and characteristics based on their creation.

During the period of Filipino ancestors women were highly valued and recognized and disrespect to them was a great sin in society (Saldua, 2012). Unfortunately, when the times of conquest and wars came, respect for women was replaced by blasphemy. During the stay of the Spaniards in the Philippines, Filipino (Nuñeza Jr. and Menchavez Sr, 1985) women experienced oppression and exploitation. The same thing happened when came the American and Japanese conquest, women also suffered cruelty and mistreatment.

Even after the dark past of women at the hands of conquerors it seems that people have forgotten the proper treatment to women. Women have become less recognized and deprived of the rights and respect they once enjoyed. They became meaningless in their own home and community, deprived of education, and became submissive to the will of men. The belief that they are only women has further weakened women to express their feelings.

When the time came for the call to empower women, it has spread around the world and the Philippines was one of those who seek to eliminate abuse of women. The results have been good for Filipino women but that was still not enough to meet the desired equality.

In developing countries, like the Philippines, women are generally less influential and women power are not significantly more likely than men (Dimarco, 2012). Although the constitution has given women equal rights with men, they have limited direct power to make decisions (Geleta, 2017) and the result is women face inequality at much higher 
rates and in all spheres of life (Upadhyay).

Today, the Philippine government has ensure that women will enjoy their constitutional rights, reproductive rights, political participation, suffrage, and other privileges that may be granted by law. However, these privileges are often seen only in urban areas or in very developed places. In remote areas, unless women are empowered and gender equality is achieved, women cannot play their role in economic, social, political, and environmental areas (Bayeh, 2016).

In the Philippines, it has territorial and political subdivisions such as provinces, cities, municipalities and barangays (1987 Philippine Constitution). The barangay or barrio is the smallest political unit in the country. Aside from the afore-mentioned, there is a place in the Philippines that is called sitio, a small territory within the barangay. A sitio is a small community with a small number of households. It is usually far from the center of the place where it is located. Sitios are similar to zone but the latter is closer to the center of the barangay. Since sitio is usually far from the center of the place, it is always neglected and seldom to be benefited from the programs of the government. Sometimes residents of sitios, male or female, suffer unfair treatment because they are considered as strangers by the people of the barangay having jurisdiction on it.

One of the most oppressed citizens of the sitio are women and they often experience improper treatment in the area that covers them and are often victims in their own place which made them feel weak and worthless. It cannot be denied that most of them feel unsafe when they are out of their place because of the discrimination they have experienced from the people. The belief that they are not in the same situation, same rights and recognition in the society put them in the ranks of the underprivileged especially women. Through this study, the researcher will find what actions did the local government unit of Nueva Ecija take to empower the women of sitio Alitaptap as perceived by the respondents. Specifically, it aimed to determine the level of conformity of the respondents on the actions taken by the local government unit in empowering women in the sitio, the impact of their actions to empower women, the effect of such empowerment, and its implication on peace and social order (Garay, 2018).

The study argues that empowering women will bring peace and social order in community. Hence, the study adapts the following predictions in the result of the study: 1 . Empowering women leads to peace and social order; 2 . Observance to local government programs improves public service; 3 . The greater the quality of local government unit action, the higher the degree of effectiveness.

\section{Methodology}

This study utilized a descriptive research design. A descriptive research design aims to accurately and systematically describe a population, situation or phenomenon (Mc Combes 2020). The respondents of the study were 83 residents of sitio Alitaptap, province of Nueva Ecija, Philippines. The respondents were chosen purposively based (Subia, 2018 as cited by Bustamante, 2020) on their actual knowledge, capacity and willingness to participate in the study. The questionnaire has three parts, Part I is composed of actions taken by the local government unit in empowering women, Part II is the impact of empowering women, and Part III is the effect of empowerment on women. The researcher utilized a convenient sampling procedure, meaning, those who are readily available during the time this study was conducted. Data gathered from the researcher's self-devised questionnaire were statistically performed using frequency count, percentage, and weighted mean. The scoring of the responses for the level of conformity of the respondents was: 1.00 to 1.79 Strongly Disagree; 1.80 to 2.59 Disagree; 2.60 to 3.39 Can't Say whether Agree or Disagree; 3.40 to 4.19 Agree; 4.20 to 5.00 Strongly Agree. 


\section{Results and Discussion}

\subsection{Actions Taken by the Local Government Unit}

Table 1 presents the level of conformity of the respondents to the actions taken by the local government unit in empowering women.

Table 1. Level of Conformity of the Respondents to the Action Taken by the Local Government Unit in Empowering Women

\begin{tabular}{|c|c|c|}
\hline Items & $\begin{array}{c}\text { Weighted } \\
\text { Mean }\end{array}$ & $\begin{array}{c}\text { Verbal } \\
\text { Interpretation }\end{array}$ \\
\hline 1. The leaders faithfully enforce the law relating to women's right. & 3.95 & Agree/High Level \\
\hline $\begin{array}{l}\text { 2. Leaders pay attention to the grievances of women who have been victims of } \\
\text { abuses. }\end{array}$ & 3.97 & Agree/High Level \\
\hline 3. Leaders provide accurate knowledge for women's right. & 4.07 & Agree/High Level \\
\hline $\begin{array}{l}\text { 4. Leaders actively disseminate information on women's rights through a variety of } \\
\text { means such as providing reading materials, seminars, and meetings related to the } \\
\text { development of women's personality. }\end{array}$ & 3.85 & Agree/High Level \\
\hline 5. Leaders ensure that their offices are open to women seeking their help. & 4.20 & $\begin{array}{l}\text { Strongly Agree/ } \\
\text { Very High Level }\end{array}$ \\
\hline $\begin{array}{l}\text { 6. Leaders ensure that they are ready to fight for the rights of women in their } \\
\text { jurisdiction. }\end{array}$ & 4.11 & Agree/High Level \\
\hline Overall Weighted Mean & 4.02 & Agree/High Level \\
\hline
\end{tabular}

The table revealed that the respondents have high level of conformity $(\mathrm{Wm}=4.02)$ to the actions taken by the local government to empower women in the place. The respondents understood very well with high level of affirmation that offices of the local leaders are open to women seeking their help $(\mathrm{Wm}=4.20)$. It was also clear to the respondents that local leaders ensure their readiness to fight for the rights of women(Wm=4.11/Agree) in their jurisdiction.

As evidence to the above-mentioned actions taken by the local government unit in the province, the respondents agree with high level $(\mathrm{Wm}=4.07)$ of conformity to the question that their leaders provide accurate knowledge for women's right. This result is in connection to the action taken by the local officials in providing information on women's right through reading materials, seminars, and meetings.

The respondents confirmed that their local leaders pay attention to the grievances of women who have been victims of abuses $(\mathrm{Wm}=3.97)$ and such is a prima facie evidence that their local leaders faithfully enforce the law relating to women's right(Wm-3.95). It can be noticed that both questions have obtained close result which shows that the respondents have evaluated the local government actions according to the benefits they received in enforcing the law in the province.

As to the question of leaders' active dissemination of information on women's rights by providing reading materials, seminars, and meetings related to the development of women's personality, the respondents agree $(\mathrm{Wm}=3.85)$ with high level of conformity. This is the lowest rating the local government unit received from the evaluation of the respondents. However, it does not mean that the local officials have relaxed in information dissemination since the respondents rate the question with high level of conformity.

Looking at the responses of the respondents, the data clearly shows the will of the local government officials to implement the programs of local government unit regarding the protection of women. Having a rate of 4.02 in its overall weighted mean implies that the local leaders perform their duties and obligations to promote women empowerment and protection. 


\subsection{Respondents' Description on the Impact of Empowering Women in Sitio Alitaptap, Nueva Ecija}

Table 2. Impact of Empowering Women

\begin{tabular}{|c|c|c|}
\hline Impact of Empowering Women & $\begin{array}{l}\text { Weighted } \\
\text { Mean }\end{array}$ & Verbal Interpretation \\
\hline 1. It encouraged women to have self-esteem. & 4.82 & Strongly Agree \\
\hline $\begin{array}{l}\text { 2. Empowering a woman brings woman a sense of security to her } \\
\text { person and property. }\end{array}$ & 4.64 & Strongly Agree \\
\hline 3. It promotes equality among men and women in society. & 4.54 & Strongly Agree \\
\hline 4. It improved the status of a woman in society. & 4.34 & Agree \\
\hline 5. It gave the woman more courage to participate in nation building. & 4.44 & Strongly Agree \\
\hline 6. Women use their rights to prejudice men. & 3.64 & Agree \\
\hline $\begin{array}{l}\text { 7. Laws for women were used to suppress men who are hated by } \\
\text { women. }\end{array}$ & 3.15 & $\begin{array}{l}\text { Can't Say whether Agree or } \\
\text { Disagree }\end{array}$ \\
\hline 8. Empowering women caused social unrest. & 2.96 & $\begin{array}{l}\text { Can't Say whether Agree or } \\
\text { Disagree }\end{array}$ \\
\hline $\begin{array}{l}\text { 9. Laws for women brought more power and status to women than } \\
\text { men. }\end{array}$ & 2.94 & $\begin{array}{c}\text { Can't Say whether Agree or } \\
\text { Disagree }\end{array}$ \\
\hline 10. Empowering women caused injustice on the part of men. & 2.76 & $\begin{array}{l}\text { Can't Say whether Agree or } \\
\text { Disagree }\end{array}$ \\
\hline Overall Weighted Mean & 3.82 & Agree \\
\hline
\end{tabular}

Table 2 shows the impact of empowering women on peace and social order in sitio Alitaptap and the respondents agree to all the questions given to them since the overall weighted mean in their response is 3.82 . The respondents strongly agree to the question that empowering women encouraged women to have self-esteem with a weighted mean of 4.82. They strongly affirm that empowering a woman brings woman a sense of security to her person and property $(\mathrm{Wm}=4.64)$. Moreover, the respondents strongly agree that empowering women promotes equality among men and women in the society $(\mathrm{Wm}=4.54)$, thus, it is not impossible that the respondents responded strongly agree $(\mathrm{Wm}=4.44)$ that empowering a woman gave more courage to a woman to participate in nation building since they are strongly agree that empowering women promotes gender equality in the community.

Based on the above result it is clear therefore that by making a woman feeling secure of his person and property will develop her self-esteem. Giving women self-confidence might push them to have enough courage to participate in governmental and non-governmental activities that will help for building a nation.

On the other hand, the respondents agree $(\mathrm{Wm}=4.34)$ that empowering women improved the status of women in society, but sadly, with a weighted mean of 3.64 or agree, the respondents admitted that women use their rights to prejudice men. However, such is just one compare to many advantages brought of empowering women to society. The important thing is, because of the effort of the local leaders the women improved their status in society as women.

Finally, with respect to the questions that laws for women were used to suppress men who are hated by women(Wm=3.15), empowering women caused social unrest(Wm2.96), laws for women brought more power and status to women than $\operatorname{men}(\mathrm{Wm}=2.94)$, and empowering women caused injustice on the part of $\operatorname{men}(\mathrm{Wm}=2.76)$ the respondents are neutral since they cannot say whether they agree or disagree to the questions raised. 


\subsection{Respondents' Description on the Effect of Empowerment on Women}

Table 3. Effect of Empowerment on Women

\begin{tabular}{|c|c|c|}
\hline Effect on Peace and Social Order & $\begin{array}{l}\text { Weighted } \\
\text { Mean }\end{array}$ & $\begin{array}{c}\text { Verbal } \\
\text { Interpretation }\end{array}$ \\
\hline 1. Women had a peaceful life and a better life in their home and in their society. & 4.57 & Strongly Agree \\
\hline $\begin{array}{l}\text { 2. Empowering women led to fair treatment on job opportunities including terms and } \\
\text { conditions of employment, promotions, education, fringe benefits and the likes. }\end{array}$ & 4.65 & Strongly Agree \\
\hline $\begin{array}{l}\text { 3. Married women were enlightened in their right to demand support and other rights } \\
\text { due to them from the erring husbands. }\end{array}$ & 4.21 & Strongly Agree \\
\hline $\begin{array}{l}\text { 4. Empowering women has given women the courage to defend themselves against } \\
\text { sexual violence and all forms of sexual abuse. }\end{array}$ & 4.60 & Strongly Agree \\
\hline 5. Women gained knowledge of their right to maternity benefits. & 4.37 & Strongly Agree \\
\hline $\begin{array}{l}\text { 6. Empowering women caused women to protect themselves against physical, mental, } \\
\text { emotional and financial abuse. }\end{array}$ & 4.57 & Strongly Agree \\
\hline $\begin{array}{l}\text { 7. Women became aware of the laws relating to women's right and learned to protect } \\
\text { their rights as women. }\end{array}$ & 3.63 & Agree \\
\hline 8. Women have learned to protect themselves and their children from oppression. & 3.76 & Agree \\
\hline 9. Empowering women leads men to know the right way to deal with women. & 4.12 & Agree \\
\hline $\begin{array}{l}\text { 10. Empowering women has helped our community to have a peaceful and orderly } \\
\text { society. }\end{array}$ & 4.25 & Strongly Agree \\
\hline Over All Weighted Mean & 4.27 & Strongly Agree \\
\hline
\end{tabular}

As shown in table 3, the respondents have responded to the questions with 4.27 overall weighted mean with verbal interpretation of strongly agree that they are very satisfied to the effect of the actions of their local leaders in empowering women. The respondents strongly agree $(\mathrm{Wm}=4.65)$ that empowering women in their society led to fair treatment on job opportunities, including terms and conditions of employment, promotions, educations, fringe benefits and the likes. It also caused women to protect themselves against physical, mental, emotional and financial abuse $(\mathrm{Wm}=4.57)$ in which the respondents strongly agree. The respondents, as can be seen from the table, expressed with strong affirmation that they, by empowering women, had a peaceful life and a better life in their home and in their society. In terms of giving birth or miscarriage, the respondents strongly agree that women gained knowledge of their rights to maternity benefits $(\mathrm{Wm}=4.37)$. With respect to the question as to empowering women has helped their community to have a peaceful and orderly society, the respondents have responded strongly agree with a weighted mean of 4.25. Respondents have strong affirmation $(\mathrm{Wm}=21)$ to the question that married women were enlightened in their right to demand support and other rights due to them from the erring husbands.

Not only the women in the sitio Alitaptap were learned, one of the effects of empowering women in their place was, it leads men to know how to deal with women in a right way with 4.12 weighted mean or they agree. Respondents agree with a weighted mean of 3.76 that women have learned to protect themselves and their children from oppression. Because of the actions of the local leaders to empower women, respondents also agree $(\mathrm{Wm}=3.63)$ that women became aware of the laws relating to women's right and learned to protect their rights as woman.

\section{The Implication of Empowerment on Women to Peace and Social Order}

The Philippines provides protection for women. The 1987 Philippine Constitution, Art. II, section 14 maintains that the State shall ensure the fundamental equality before the law of women and men. The Magna Carta of Women of 2009 holds that the state realizes the equality of men and women entails the abolition of the unequal structures and practices that perpetuate discrimination and inequality. Protection for women can be achieved through appropriate rules, regulations, plans, policies, and actions. Through the actions of the government for women protection, the Philippines has almost attain the equality of women and men. The result of this study proves that empowering women will help us to save women 
from violence and discrimination and will give us a way to have a peaceful and orderly society. However, it does not mean that women are free from possible future unfair treatment. It is very evident that women enjoy this kind of privilege because they are backed up by law which is properly implemented by the local government unit. The local government unit shall continue to provide programs to empower women and implement laws for women. They should not relax for the strength of the women comes from law.

\section{Conclusions and Recommendations}

On the actions taken by the local government unit in empowering women, the respondents answered with high level of affirmation confirming that their local political leaders perform their duties and responsibilities to empower women. Their actions have resulted in women's protection and women were enlightened of their rights and learned to protect themselves and their children against oppression. These caused to women self-esteem that brought them peace in their person, home, and society. These findings showed that empowering women will bring peace and social order in the community. The local government unit's observance to the local government programs improves public service. It will make the citizens enlightened about their rights and obligations and their role to the community. This proves that the greater the quality of local government actions, the higher degree of effectiveness in the performance of duties. The only negative effect of empowerment on women is the threat that women may use their rights to prejudice men. Based on the following findings and conclusions, it is recommended that: Other research should be conducted with the same topic as to this study using people in more remote and neglected place than the place use in this study as respondents. More respondents are hereby recommended to be the subject to find a more accurate result. Despite that this study has a positive result the local political leaders in the respondents' place should not be immediately satisfied with the result of their work but think of other more productive ways to take care of women. And Finally, they shall ensure that laws are faithfully executed for all regardless of gender.

\section{References}

Bayeh, E. (2016). The Role of Empowering Women and Achieving Gender Equality to the Sustatinable Development of Ethiopia. Pacific Science Review B: Humanities and Social Sciences, $2(1), \quad 37-42$. https://doi.org/10.1016/j.psrb.2016.09.013

Bustamante, J. Y. (2020). Level of Understanding in Political Dynasty of College Students: Its Implication on Equal Access to Public Service. International Journal of English Literature and Social Sciences(IJELS), ISSN:2456-7620, 5(4), 1332-1336. https://doi.org/10.22161/ijels.54.76

Dimarco, N. (2012). Thesis: Female Leaders and Women's Empowerment: Case Studies. Retrieved from: https://academicworks.cuny.edu/cgi/viewcontent.cgi?article=1101\&context=cc_etds_theses

Garay, J. (2018). Thesis: Public Perception on Drug-related Killings in General Santos City. Retrieved from: www.researchgate.net/publication/331832771

Geleta, E. B., et.al. (2017). The Challenges of Empowering Women: The Experience of Pulse Innovation Project in Southern Ethiopia.https://doi.org/10.1177/2158244017736802

Mc Combes, S. (2020). Descriptive Research. Revised on September 3, 2020. Retrieved from: www.scribbr.com/methodology/descriptive-research/

Nuñeza Jr, N. M., \& Menchavez Sr, J. D. (1985). Jubilee book and updated by Joel L. Molit and Nelson J. Ares. Retrieved form: catmoncebu.webs.com/history/feat_munhistory.html

R. A. 9710. (2009). The Magna Carta of Women. Chapter 1, sec. 2. Retrieved from: http://hrlibrary.umn.edu/research/Philippines

Saldua, A. D. I. R. (2012). The Role of Women from Pre-Hispanic to Spanish Era. Retrieved from: https://tonkshistory.wordpress.com

The 1987 Philippine Constitution, Art. II. Sec. 14.

Upadhyay, R. The Asia Foundation: Women's Empowerment in India An Analytical Overview. Retrieved from: https://asiafoundation.org/resources/pdfs/womensempowermentindiabriefs.pdf

\section{Copyrights}

Copyright for this article is retained by the author(s), with first publication rights granted to the journal.

This is an open-access article distributed under the terms and conditions of the Creative Commons Attribution license which permits unrestricted use, distribution, and reproduction in any medium, provided the original work is properly cited. 